\title{
Characterization of bacteriocin $A B C$ transporter ATP-binding protein produced by a newly isolated Enterococcus casseliflavus MI001 strain
}

Indira Mikkili ${ }^{1}$, Venkateswarulu TC ${ }^{1 *}$, Abraham Peele Karlapudi ${ }^{1}$, Vidya Prabhakar Kodali ${ }^{2}$ and Krupanidhi Srirama ${ }^{1^{*}}$

\begin{abstract}
Background: ATP-binding cassette $(A B C)$ transporters constitute one of the largest transporter protein families and play a role in diverse biological processes.

Results: In the present study, bacteriocin isolated from the Enterococcus casseliflavus MI001 strain was identified as an $A B C$ transporter ATP-binding protein. The optimal conditions for the production of bacteriocin were found to be at $35^{\circ} \mathrm{C}$, a pH 5.5, and an incubation time of $24 \mathrm{~h}$. Purification was performed using ammonium sulphate precipitation, gel filtration, and DEAE ion exchange chromatography. The bacteriocin was purified with an eightfold purification scheme resulting with a specific activity of 15,000 AU/mg. The NMR spectrum of purified bacteriocin revealed the presence of amino acids, namely lysine, methionine, cysteine, proline, threonine, tryptophan, and histidine. Further, the bacteriocin $A B C$ transporter showed antimicrobial activity against food spoilage microorganisms.
\end{abstract}

Conclusions: The ABC transporter ATP-binding protein could be used as a potential alternative for food preservation, and it may be considered as a bio-preservative agent in food processing industries.

Keywords: Bacteriocin, Enterococcus casseliflavus MI001 strain, ABC transporter, Three-step purification, NMR spectrum

\section{Introduction}

Living organisms depend on various means of transport for the uptake of external nutrients and sequestration of waste products into the surrounding environment [3]. ATP-binding cassette (ABC) transporters are one of the largest super families of transport proteins present in all forms of life. They play diverse roles in both prokaryotes and eukaryotes. These transporters are the primary transporters functioning as both importers and exporters. Importers mediate the uptake of essential nutrients, vitamins,

\footnotetext{
* Correspondence: venki_biotech327@yahoo.com;

krupanidhijuly2012@gmail.com

'Department of Bio-Technology, Vignan's Foundation for Science,

Technology \& Research, Vadlamudi, Andhra Pradesh 522213, India

Full list of author information is available at the end of the article
}

and trace metals from the surrounding environment, whereas exporters export substrates to the surrounding environment. Based on the type of substrate exported, they are categorized into various types. One such substrate is bacteriocin, and the transporter proteins exporting bacteriocin are called bacteriocin $A B C$ transporters. They export bacteriocin across the cell membrane via a proteolytic function. The proteolytic domain resides in the $\mathrm{N}$-terminal region, the $\mathrm{ABC}$ transporter domain is in the $\mathrm{C}$-terminal and central multi-pass transmembrane region. Bacteriocins synthesized as propeptides are processed through this $\mathrm{ABC}$ transporter system and exported from cells as mature peptides [7]. Bacteriocins are secreted by either a double glycine leader in the N-terminal part of the pre-bacteriocin or secreted by a sec-system [12]. Due to the presence of a glycine leader on the $\mathrm{N}$ - 

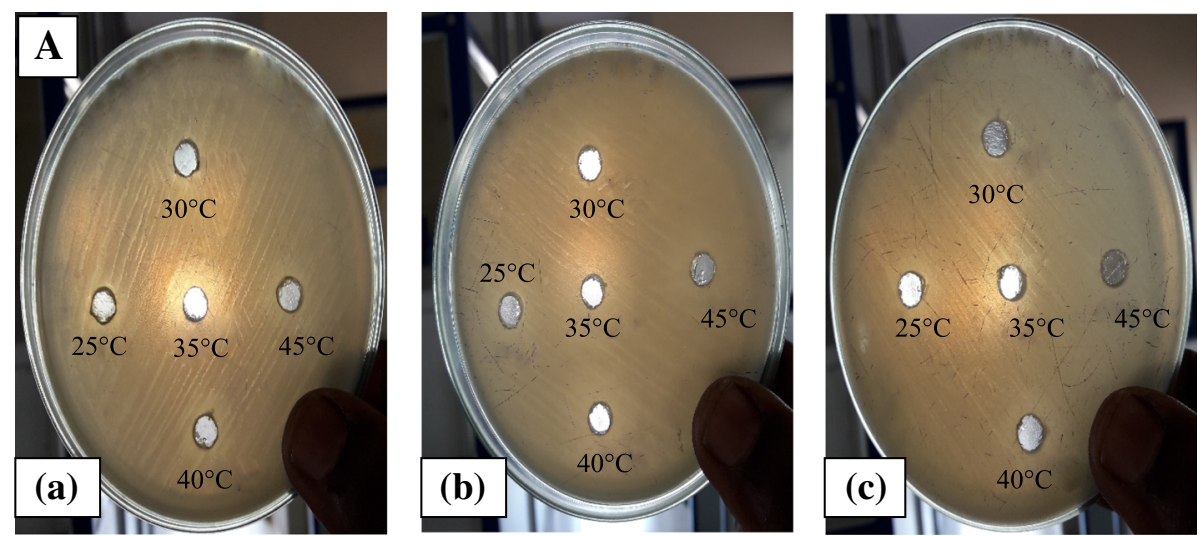

Fig. 1 A Effect of temperature on bacteriocin production after $24 \mathrm{~h}$ against (a) P. aeruginosa, (b) S. aureus, and (c) E.coli

terminal side, these transporters remove the $\mathrm{N}$-terminal leader peptide from its bacteriocin precursor by cleavage at a Gly-Gly bond and transport the mature bacteriocin across the cytoplasmic membrane. The transporter acts as an efflux system, which helps the secretion of bacteriocins, proteins, polysaccharides, toxic compounds, and enzymes. The importance of these transporters in the multiple cellular functions and biosynthetic pathways of bacteria represents a novel strategy for the secretion of bacterial proteins and points out potential drug targets [10]. ABC transporters were found to play a key role in virulence and also identified as suitable targets for the development of antibacterial vaccines $[1,4]$. However, an improved understanding of the structure, function, and action mechanism of these transporters have enabled us to develop new approaches for investigating lead molecules in terms of treating various diseases caused by problematic organisms [8]. An attempt has been made to characterize the bacteriocin $\mathrm{ABC}$ transporter ATP-binding protein from the Enterococcus casseliflavus MI001 strain.

\section{Methods}

\subsection{Bacterial strains and culture medium}

The indicator organisms were procured from the MTCC at the Institute of Microbial Technology, Chandigarh. The cultures were revived and stored in refrigerated conditions for further work. A nutrient broth medium (Hi-Media Chemicals, India) was used for maintenance and growing the indicator organisms for bacteriocin activity. The de Man, Rogosa, and Sharpe (MRS) broth medium (Hi-Media Chemicals, India) was used for production of the bacteriocin. Finally, the Muller-Hinton agar (Hi-Media Chemicals, India) medium was used for bacteriocin activity.

\subsection{Optimization of culture conditions for bacteriocin production}

2.2.1 Effect of incubation temperature and $\mathrm{pH}$ on bacteriocin production

Optimum conditions were determined by growing the test organism at a wide range of temperatures and $\mathrm{pH}$ values. The MRS broth was inoculated with $E$. casseliflavus MI001 and incubated at different temperatures
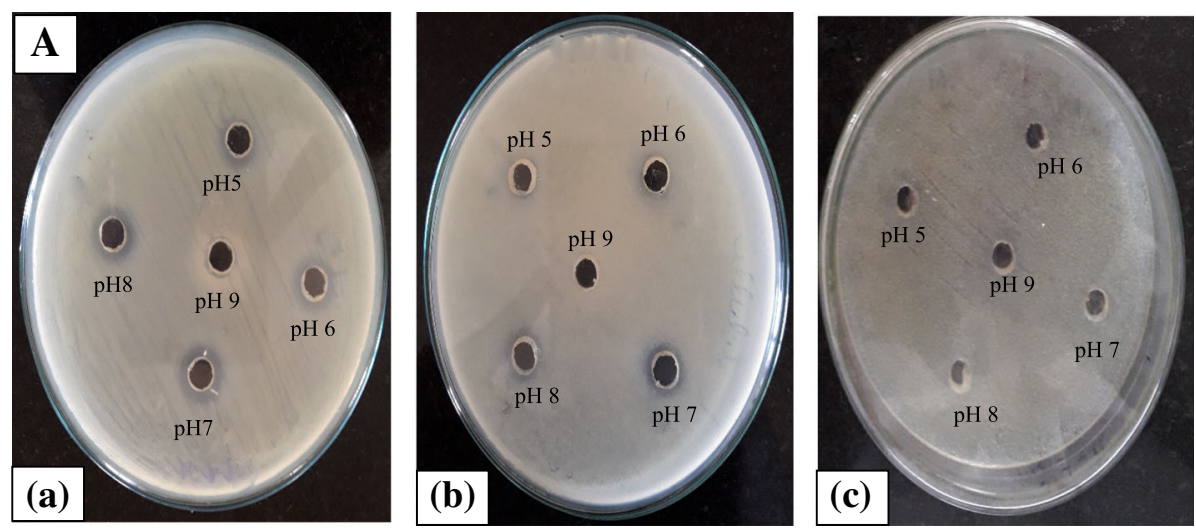

Fig. 2 A Effect of $\mathrm{pH}$ on bacteriocin production after $24 \mathrm{~h}$ against (a) P. aeruginosa, (b) S. aureus, and (c) E.coli at $37^{\circ} \mathrm{C}$ 


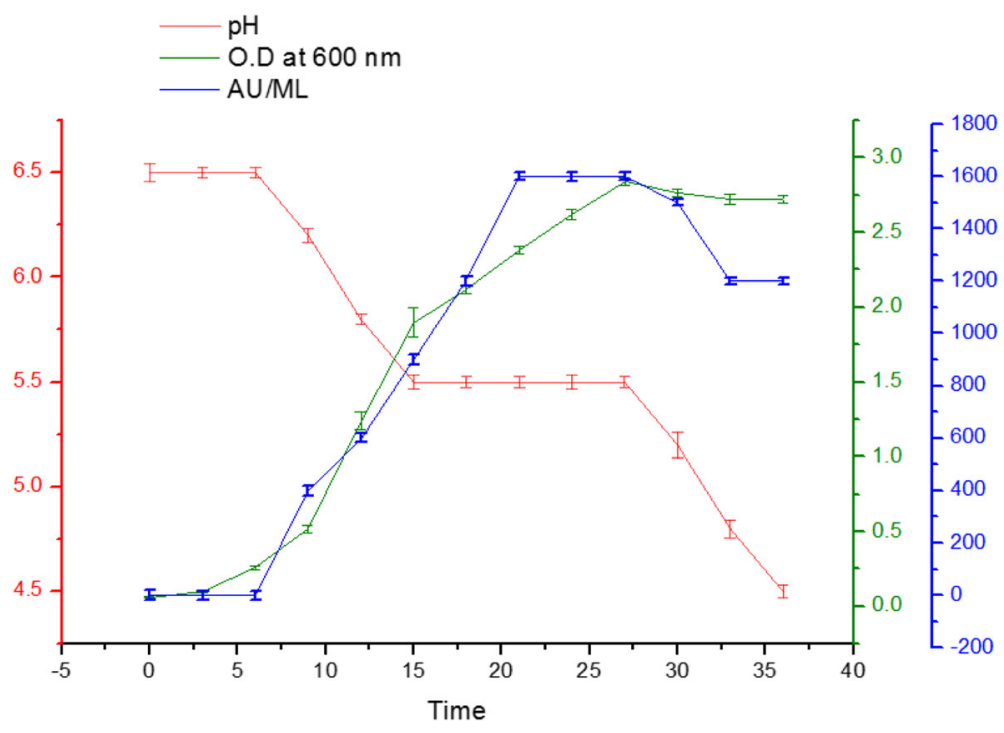

Fig. 3 Growth curve and bacteriocin production by Enterococcus casseliflavus MI001 strain

$\left(25^{\circ} \mathrm{C}, 30^{\circ} \mathrm{C}, 35^{\circ} \mathrm{C}, 40^{\circ} \mathrm{C}\right.$, and $\left.45^{\circ} \mathrm{C}\right)$ and $\mathrm{pH}$ values ranging from 5 to 9 for $48 \mathrm{~h}$. The samples were centrifuged at $10,000 \mathrm{rpm}$ for $15 \mathrm{~min}$. The supernatant collected was assayed for bacteriocin activity via the agar well diffusion method $[15,16]$.

\subsubsection{Growth curve and production of bacteriocin}

For growth curve measurement and production of bacteriocin, MRS broth (dextrose-20 g, peptone-10 $\mathrm{g}$, beef extract $-8 \mathrm{~g}$, yeast extract $-4 \mathrm{~g}$, dipotassium phosphate $-2 \mathrm{~g}$, triammonium citrate $-2 \mathrm{~g}$, sodium acetate $-5 \mathrm{~g}$, magnesium sulphate $-0.2 \mathrm{~g}$, manganese sulphate $-0.05 \mathrm{~g}$, Tween $80-1 \mathrm{~g}$, distilled water -1000 $\mathrm{ml}$ ) with a $\mathrm{pH}$ of $6.5-7.0$ was inoculated with $1 \% \mathrm{v} / \mathrm{v}$ of overnight-grown E. casseliflavus MI001, then incubated at $35^{\circ} \mathrm{C}$ for $36 \mathrm{~h}$. For every 3 -h time interval, the optical density at $600 \mathrm{~nm}$ and $\mathrm{pH}$ were determined. Bacteriocin activity was determined every $3 \mathrm{~h}$ by agar well diffusion assay. Bacteriocin activity was measured using the formula $\mathrm{AU} / \mathrm{mL}=1000 / V \times D$ (where AU stands for arbitrary unit, $V$ is the volume of the cell-free supernatant, and $D$ is the dilution factor). Specific activity was measured as bacteriocin activity (AU)/total protein (mg) [17].

\subsubsection{Purification of bacteriocin}

Cell-free supernatant was saturated using $70 \%$ ammonium sulphate at ice-cold conditions $\left(4^{\circ} \mathrm{C}\right)$ with continuous stirring $(300 \mathrm{rpm})$ and incubated overnight to precipitate the proteins. The precipitate was centrifuged at $6000 \mathrm{rpm}$ for $10 \mathrm{~min}$ and dialyzed overnight at $4{ }^{\circ} \mathrm{C}$ using a $5 \mathrm{mM}$ Tris buffer ( $\left.\mathrm{pH} 7.0\right)$. The dialysis sample was subjected to gel filtration chromatography using Sephadex G25 (13 mm radius $\times 150 \mathrm{~mm}$ length) pre-equilibrated with $100 \mathrm{mM}$ phosphate buffer ( $\mathrm{pH} 7.0$ ), and the flow rate was set to $1 \mathrm{ml} / 5 \mathrm{~min}$ using the same buffer. The active fractions collected from the gel filtration chromatography were subjected

Table 1 Summary of purification profile of bacteriocin ABC transporter ATP-binding protein produced by Enterococcus casseliflavus MI001 strain

\begin{tabular}{llllll}
\hline Type of sample & Volume collected $(\mathrm{ml})$ & Total protein $(\mathrm{mg})$ & Total activity (AU) & Specific activity (AU/mg) & Fold purification \\
\hline Crude & 150 & 129 & 240,000 & 1860 & 1 \\
$\begin{array}{l}\text { Ammonium sulphate precipitation } \\
\text { and dialysis }\end{array}$ & 10 & 3.6 & 18,000 & 5000 & 2.688 \\
$\begin{array}{l}\text { Gel filtration chromatography } \\
\text { (SephadexG-75) }\end{array}$ & 5 & 1.2 & 11,000 & 9166 & 4.927 \\
$\begin{array}{l}\text { lon exchange chromatography } \\
\text { (DEAE cellulose) }\end{array}$ & 2 & 0.32 & 4800 & 15,000 & 8.064 \\
\hline
\end{tabular}




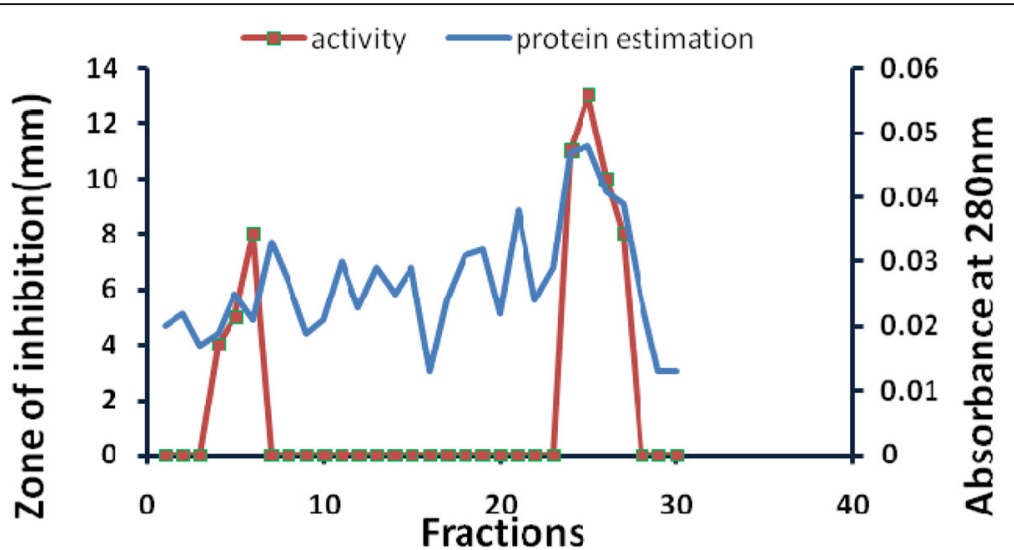

Fig. 4 Purification of bacteriocin by gel filtration chromatography. The blue line shows the protein content in terms of absorbance values at $280 \mathrm{~nm}$, and the brown line shows the peak pertaining to bacteriocin activity

to ion exchange chromatography using a DEAE cellulose column ( $13 \mathrm{~mm}$ radius $\times 150 \mathrm{~mm}$ length) equilibrated with $25 \mathrm{mM}$ Tris- $\mathrm{HCl}$ and $25-150 \mathrm{mM} \mathrm{NaCl}$ buffers ( $\mathrm{pH}$ 7.0) [16]. The protein concentration was determined for all fractions, and an antimicrobial assay was performed against Staphylococcus aureus.

\subsubsection{FTIR spectroscopy and NMR analysis}

The purified fraction collected was subjected to FTIR analysis, and the spectrum was recorded in the frequency range of 4000 to $400 \mathrm{~cm}^{-1}$ using Agilent Technologies. The NMR spectrum was recorded for a purified sample using a Bruker $400-\mathrm{MHz}$ spectrophotometer at $295 \mathrm{~K}$.
The purified bacteriocin sample was dissolved in methanol and analysed for ${ }^{1} \mathrm{H}$ and ${ }^{13} \mathrm{C}$ NMR spectra. The chemical shifts were recorded using tetramethylsilane (TMS) as an internal reference [9].

\section{Results and discussion}

\subsection{Optimization of culture conditions for bacteriocin activity}

3.1.1 Effect of temperature

Temperature influences the growth and production of bacteriocin, and it is one of the physical factors that play an important role in the metabolic activities of bacteria. From Fig. 1A (a, b, c), it was found that the

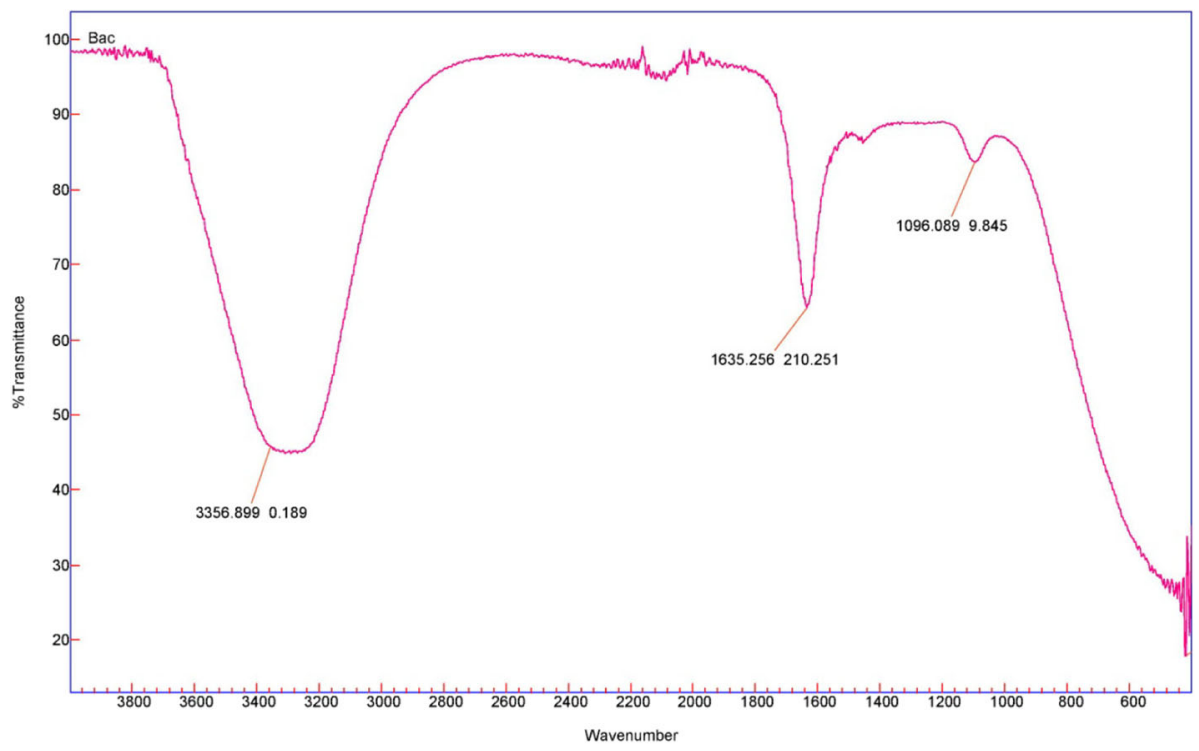

Fig. 5 FT-IR spectral analysis of purified bacteriocin from Enterococcus casseliflavus MI001 strain 
Table 2 Wave number represents the presence of bonds

\begin{tabular}{lll}
\hline Wave number $\mathrm{cm}^{-1}$ & Possible bonds & Intensity \\
\hline 3367.186 & Amine stretch $(\mathrm{N}-\mathrm{H})$ & Medium \\
1635.441 & Alkene $(\mathrm{C}=\mathrm{C})$ & Variable \\
1096.238 & $\mathrm{C}-\mathrm{N}$ & Medium, weak \\
\hline
\end{tabular}

E. casseliflavus MI001 grown in MRS broth at $35^{\circ} \mathrm{C}$ showed high antimicrobial activity against the indicator organisms Pseudomonas aeruginosa, S. aureus, and Escherichia coli after $24 \mathrm{~h}$ of incubation, which disappeared after $48 \mathrm{~h}$ of incubation. After an increase in temperature up to $40^{\circ} \mathrm{C}$ for $24 \mathrm{~h}$ of incubation, bacteriocin production was at a minimum, as it showed a reduction in antimicrobial activity. Bacteriocin activity was not observed at temperatures of $25^{\circ} \mathrm{C}, 30^{\circ} \mathrm{C}$, and $45^{\circ} \mathrm{C}$ when incubated for 24 and $48 \mathrm{~h}$. Zotta et al. [18] also reported that the cultivation of Lactobacillus plantarum at $25^{\circ} \mathrm{C}$ reduced the growth compared to the optimal temperature of $35^{\circ} \mathrm{C}$. Our results suggest that the bacterium is surviving in human body conditions; this feature helps in that this organism could be used as a probiotic. In consonance, a recent study by Phumisantiphong et al. [13] reported that the bacteriocin production from Enterococcus faecalis 478 was found to be high at $37^{\circ} \mathrm{C}$.

\subsection{Effect of $\mathrm{pH}$}

The synthesis of metabolites and metabolic activities of bacteria are usually affected by varying the $\mathrm{pH}$. It was found that E. casseliflavus MI001 incubated for $24 \mathrm{~h}$ at $\mathrm{pH}$ 5.0-8.0 supported the growth and production of bacteriocin with good antimicrobial activity, as represented in Fig. 2A (a, b, c). The bacteriocin activity was not observed at acidic $\mathrm{pH}$ values and above a $\mathrm{pH}$ of 9.0. This result suggests that the bacteriocin activity is not due to organic acid production by bacteria. Iyapparaj et al. [6] reported that high bacteriocin production was recorded above a $\mathrm{pH}$ of 5.0, and reduced activity was observed at a $\mathrm{pH}$ of 9.0.

\subsection{Growth curve and production of bacteriocin}

Growth of the bacterium under various physical conditions, along with medium components, is important for the production of bacteriocin. MRS is a complex synthetic medium which supports bacteriocin production. Higher bacteriocin production was observed at a temperature of $35^{\circ} \mathrm{C}$, a pH of 5.5 , and $27 \mathrm{~h}$ of incubation time, as represented in Fig. 3. Bacteriocin production was high during the exponential phase and was found to be $1500 \mathrm{AU} / \mathrm{ml}$. A reduction in bacteriocin production was observed at temperatures above $35^{\circ} \mathrm{C}, \mathrm{pH}$ values below 4.5 , and incubation times in excess of $30 \mathrm{~h}$. In a previous report by Todorov et al. [17], it was found that the production of bacteriocin was high at $37^{\circ} \mathrm{C}$ and $\mathrm{pH}$ 5.5. According to Fabricio et al. [2], bacteriocin production was high at $37^{\circ} \mathrm{C}, \mathrm{pH} 5.0$, and an incubation time of $8 \mathrm{~h}$ during the exponential growth phase.

\subsection{Purification of bacteriocin}

The crude extract produced by Enterococcus casseliflavus MI001 was purified by a three-step procedure, as represented in Table 1. The crude extract precipitated with $70 \%$ ammonium sulphate increased the specific activity about 2.6 -fold. The active sample purified by gel filtration chromatography showed two peaks, the specific activity increased about 4.9-fold, and the fractions from 24 to 28 showed high antimicrobial activity against the $S$. aureus $(15 \mathrm{~mm})$ (Fig. 4). In anion exchange chromatography, an 8.0-fold increase in specific activity at 15,000 AU/mg was observed. During each purification step, a considerable loss in protein concentration and a marked increase in the specific activity of the bacteriocin were observed. The purified fraction containing bacteriocin revealed the molecular weight of a $22-\mathrm{kDa}$ protein via

Table $3{ }^{13} \mathrm{C}$ NMR spectral data. Various groups of carbon being detected in purified bacteriocin ABC transporter isolated from $E$. casseliflavus MI001 strain

\begin{tabular}{lll}
\hline${ }^{13} \mathrm{C}$ NMR spectra standard values & & $\begin{array}{l}\text { Purified bacteriocin sample NMR spectra (predicted values) } \\
\text { Chemical shift (ppm) }\end{array}$ \\
\hline Carbon environment & Chemical shift (ppm) & $217.51,207.26$ \\
\hline $\mathrm{C}=\mathrm{O}$ (in ketones) & $205-220$ & 146.65 \\
$\mathrm{C}$ in aromatic rings & $125-150$ & $115.46,114.12,112.90$ \\
$\mathrm{C}=\mathrm{C}$ (in alkenes) & $115-140$ & 96.57 \\
$\mathrm{C}=\mathrm{C}$ (in alkynes) & $90-100$ & $80.02,61.16,58.24$ \\
$\mathrm{RCH}_{2} \mathrm{O}-$ & $50-90$ & $49.86,49.64,49.43,49.21,49.01,48.79,48.57$ \\
$\mathrm{RCH}_{2} \mathrm{Cl}$ & $30-60$ & \\
$\mathrm{RCH}_{2} \mathrm{NH}_{2}$ & $30-65$ & \\
\hline
\end{tabular}



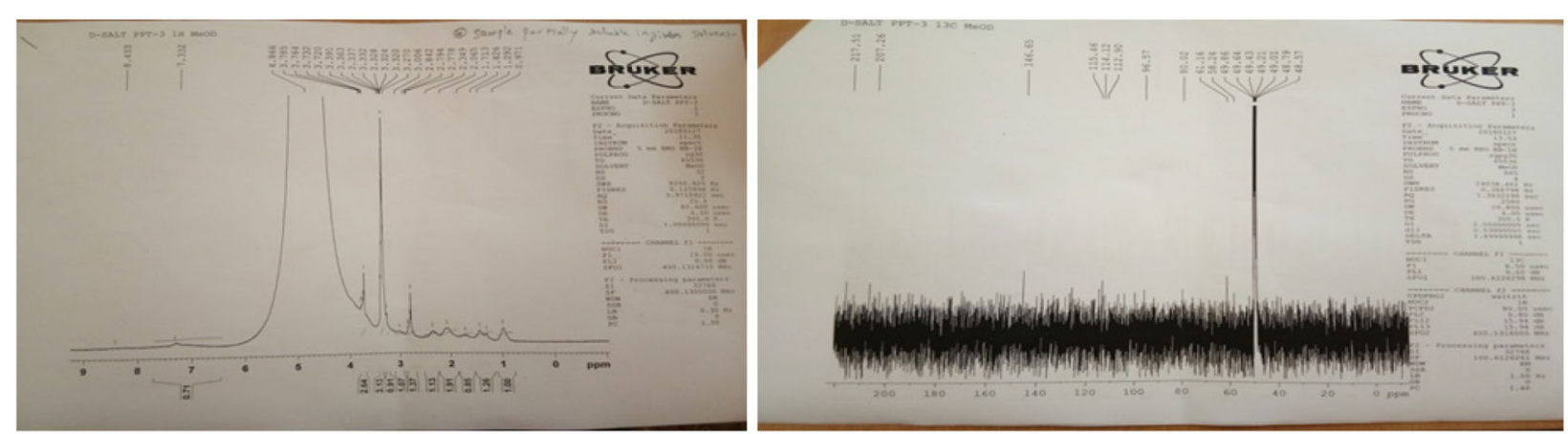

Fig. $6{ }^{13} \mathrm{C}$ NMR spectra (Left) and ${ }^{1} \mathrm{H}$ spectra (Right) of purified bacteriocin isolated from E. casseliflavus MI001 strain

SDS-PAGE [5]. In a recent study reported by Qianwen et al. [14], it was found that the bacteriocin produced by Enterococcus faecalis TG2 has a molecular weight of $6.33 \mathrm{kDa}$ protein using a three-step purification procedure.

\subsection{FTIR spectrum and NMR spectral analysis}

The FTIR spectral analysis showed the presence of a $\mathrm{C}=\mathrm{C}$ stretch and amine group coupled with a $\mathrm{C}-\mathrm{N}$ group (Fig. 5). The correlation of various peaks is represented in Table 2. A previous study by Kadirvelu et al. [9] reported the presence of an amide and hydroxyl group coupled with $\mathrm{C}-\mathrm{H}$. Further, ${ }^{13} \mathrm{C}$ NMR and ${ }^{1} \mathrm{H}$ NMR analyses were carried out to discover the different amino acids and carbon compounds forming the molecular structure of the bacteriocin of Enterococcus casseliflavus MI001. The NMR spectra obtained were compared with the standard ${ }^{13} \mathrm{C}$ NMR spectrum presented in Table 3. From Fig. 6, it can be seen that the ${ }^{13} \mathrm{C}$ NMR showed the presence of 17 carbons, of which 2 are in $\mathrm{C}=\mathrm{O}$ (ketones), 1 is in an aromatic ring, 3 are in $\mathrm{C}=\mathrm{C}$ (alkenes), 1 is in $\mathrm{C}=\mathrm{C}$ (alkyne), 3 are in $\mathrm{R}$ $\mathrm{CH}_{2} \mathrm{O}$, and 7 are in the carbon environment $\mathrm{R}$ $\mathrm{CH}_{2} \mathrm{Cl}$ and $\mathrm{RCH}_{2} \mathrm{NH}_{2}$. The ${ }^{1} \mathrm{H}$ NMR spectrum was compared with the peaks of a standard spectrum of 20 amino acids. Of the 20 amino acids, seven, viz., lysine, methionine, cysteine, proline, threonine, tryptophan, and histidine, were involved in forming the peptide structure of the bacteriocin of E. casseliflavus MI001, as represented in both Fig. 6b (Right) and Table 4. In a previous study by Neha et al. [11], it was reported that the purified bacteriocin of Lactobacillus brevis UN examined by a ${ }^{1} \mathrm{H}$ NMR spectrum exhibited the following amino acids: proline, glutamic acid, arginine, leucine, isoleucine, and serine.

\section{Conclusions}

In this study, the optimized conditions for the bacteriocin production and three-step procedure for purification yielded a bacteriocin peptide molecule with antimicrobial activity. The purified bacteriocin molecular weight was found to be $22 \mathrm{kDa}$, which matched the results from MALDI-TOF. The ${ }^{13} \mathrm{C}$ NMR and ${ }^{1} \mathrm{H}$ NMR analyses revealed that the carbon environment and combinations of the unique amino acids in purified bacteriocin result in antibacterial activity, which has been reported for the first time through the present study. The antimicrobial activity of this $\mathrm{ABC}$ transporter bacteriocin has attracted much attention due to the antimicrobial resistance of the bacteria, which can be used as a next-generation antimicrobial in various fields.

Table $4{ }^{1} \mathrm{H}$ NMR spectral data, delta (ppm) of various amino acids detected in purified bacteriocin of E. casseliflavus MI001

\begin{tabular}{lll}
\hline Name of the amino acid & Chemical shift $(\mathrm{ppm})$-standard values & Chemical shift (ppm)_predicted values \\
\hline Lysine & 1.7 & 1.713 \\
Methionine & 2.0 & 2.065 \\
Cysteine & 3.2 & 3.270 \\
Proline & $2.1-3.6$ & $3.320-3.391$ \\
Threonine & $4-5$ & 4.866 \\
Tryptophan & $6.5-7.8$ & 7.332 \\
Histidine & $6.5-8.5$ & 8.433 \\
\hline
\end{tabular}




\section{Abbreviations}

ABC: ATP-binding cassette; MTCC: Microbial Type Culture Collection; NMR: Nuclear magnetic resonance

\section{Acknowledgements}

The authors would like to acknowledge the facilities supported by DST-FIST and Vignan's Foundation for Science Technology and Research (Deemed to be University), Guntur, India.

\section{Authors' contributions}

$\mathrm{Ml}$ carried out the experimental studies and drafted the manuscript. SK and KV participated in the design of the study. KA and TCV participated in optimization studies. KA and TCV conceived of the study, participated in its design and coordination, and helped to draft the manuscript. All authors read and approved the final manuscript.

\section{Funding}

Not applicable.

\section{Availability of data and materials}

All data generated or analysed during this study are included in this published article.

\section{Ethics approval and consent to participate}

Not applicable.

\section{Consent for publication}

Not applicable.

\section{Competing interests}

The authors declare that they have no competing interests.

\section{Author details}

'Department of Bio-Technology, Vignan's Foundation for Science, Technology \& Research, Vadlamudi, Andhra Pradesh 522213, India. 2Department of Bio-Technology, Vikrama Simhapuri University, Nellore, Andhra Pradesh 524001, India.

Received: 5 July 2019 Accepted: 26 July 2019

Published online: 12 September 2019

\section{References}

1. Davidson AL, Elie D, Cedric O, Jue C (2008) Structure, function, and evolution of bacterial ATP-binding cassette systems. Microbiol Mol Biol Rev 72:317-364

2. Fabricio LT, Bruna CG, Elaine CPDM (2011) Partial purification and characterization of a bacteriocin produced by Enterococcus faecium 130 isolated from mozzarella cheese. Ciencia e Tecnologia de Alimentos 31: 155-159

3. Gizaw M, Anandakumar P (2017) A review on ATP binding cassette (ABC) transporters. Int J Pharma Res Health Sci 5:1607-1615

4. Helen SG, Richard WT (2004) ATP-binding cassette transporters are targets for the development of antibacterial vaccines and therapies. Infect Immun 72:6757-6763

5. Indira M, Venkateswarulu TC, Vidya Prabhakar K, Abraham Peele K, Krupanidhi S (2018) Isolation and characterization of bacteriocin producing Enterococcus casseliflavus and its antagonistic effect on Pseudomonas aeruginosa. Karbala Int J Modern Sci 4:361-368

6. Iyapparaj $P$, Thirumalai M, Ramasamy $R$, Santhiyagu P, Chandrasekaran K Grasian I, Arunachalam P (2013) Optimization of bacteriocin production by Lactobacillus sp. MSU3IR against shrimp bacterial pathogens. Aquatic Biosystems 9:12

7. Jan M, Gunter D, Jos V, Chuanwu X (2001) Processing and export of peptide pheromones and bacteriocins in Gram negative bacteria. Trends Microbiol 9(4):164-168

8. Joni T, Glenn ST (2010) ABC transporters in microorganisms. Expert Rev Anti-Infect Ther 8(4):375-377

9. Kadirvelu J, Venkatasubramanian V, Perumal JA, Appukuttan S, Muthukandan $U$ (2015) Characterization of an antibacterial compound, 2-hydroxyl indole-3-propanamide, produced by lactic acid bacteria isolated from fermented batter. Appl Biochem Biotechnol 177:137-147
10. Murphy TF, Brauer AL, Johnson AKC (2016) ATP-binding cassette (ABC) transporters of the human respiratory tract pathogen, Moraxella catarrhalis: role in virulence. PLoS One 11(7):e0158689

11. Neha G, Nivedita S, Ahlawat OP (2014) Purification and characterization of bacteriocin produced by Lactobacillus brevis UN isolated from Dhulliachar: a traditional food product of north East India. Indian J Microbiol 54(2):185-189

12. Ness IF, Dzung BD, Yasuyoshi I (2014) Enterococcal bacteriocins and antimicrobial proteins that contribute to niche control. In: Gilmore MS, Clewell DB, Ike $Y$ et al (eds) Enterococci: from commensals to leading causes of drug resistant infection. Massachusetts Eye and Ear Infirmary, Boston

13. Phumisantiphong $U$, Siripanichgon K, Reamtong O, Diraphat $P$ (2017) A novel bacteriocin from Enterococcus faecalis 478 exhibits a potent activity against vancomycin-resistant enterococci. PLoS One 12(10): e0186415

14. Qianwen X, Jin W, Renpeng D, Fangkun Z, Han Y, Zhijiang Z (2018) Purification and characterization of bacteriocin produced by a strain of Enterococcus faecalis TG2. Appl Biochem Biotechnol 184:1106-1119

15. Sivaramasamy E, Neelamegam A, Packiyam M, Thangavel B (2014) Production, purification and characterization of bacteriocin from Lactobacillus murinus AU06 and its broad antibacterial spectrum. Asian Pac Trop Biomed 4(11):S305-S311

16. Sure KP, Kotnis PV, Bhagwat PK, Ranveer RC, Dandge PB, Sahoo AK (2016) Production and characterization of bacteriocin produced by Lactobacillus viridescence (NICM 2167). Braz Arch Biol Technol 59. e16150518

17. Todorov SD, Manuela V, Bernadette DGF, Wilhelm HH (2013) Partial characterization of bacteriocins produced by three strains of Lactobacillus sakei, isolated from salpicao, a fermented meat product from North-West of Portugal. Food Control 30:111-121

18. Zotta T, Guidone A, lanniello RG, Parente E, Ricciardi A (2013) Temperature and respiration affect the growth and stress resistance of Lactobacillus plantarum C17. J Appl Microbiol 115(3):848-858

\section{Publisher's Note}

Springer Nature remains neutral with regard to jurisdictional claims in published maps and institutional affiliations.

\section{Submit your manuscript to a SpringerOpen ${ }^{\circ}$ journal and benefit from:}

- Convenient online submission

- Rigorous peer review

- Open access: articles freely available online

High visibility within the field

- Retaining the copyright to your article

Submit your next manuscript at $\boldsymbol{\nabla}$ springeropen.com 